\title{
Phenotype of patients with congenital adrenal hyperplasia due to $11 \beta$-hydroxylase deficiency
}

\author{
Vu Chi Dung ${ }^{1 *}$, Nguyen Phuong Mai ${ }^{1}$, Nguyen Huy Hoang ${ }^{2}$, Bui Phuong Thao ${ }^{1}$, Nguyen Ngoc Khanh', \\ Can Thi Bich Ngoc ${ }^{1}$, Nguyen Phu Dat ${ }^{1}$
}

From 8th APPES Biennial Scientific Meeting

Darwin, Australia. 29 October - 1 November 2014

Congenital adrenal hyperplasia $(\mathrm{CAH})$ is one of the most common metabolic diseases. It is caused by a severe or partial impairment of adrenal steroidogenesis affecting cortisol biosynthesis. Approximately $5-8 \%$ of all cases are due to steroid $11 \beta$-hydroxylase deficiency (11OHD; OMIM +202010), which occurs in approximately $1: 100,000$ to $1: 200,000$ live births in non consanguineous populations. Mutations in the CYP11B1 gene, causing 11b-hydroxylase deficiency in the zona fasciculate in the adrenal cortex, have been identified. Our aim is to describe clinical and biochemical features in patients with $\mathrm{CAH}$ due to $11 \beta$-hydroxylase deficiency. The case series report included 9 patients $(6$ male and 3 female) from 7 unrelated families who was identified novel and/or reported homozygous or compound heterozygous mutations in CYP11B1 gene. Diagnosed age was from 2 to 11 years old. All three female cases presented with ambiguous genitalia at birth. Other clinical features were hypertension (6/7 cases); hyperpigmentation (5/7 cases); pseudo-precocious puberty (male) $(5 / 5$ cases). Hypokalemia was noted in 3/7 cases. Three cases need antihypertensive drug associated with hydrocortisone replacement therapy. In conclusions, the clinical hallmark of $11 \beta$ hydroxylase deficiency is variable and virilization and hypertension are the prominent clinical features of $11 \mathrm{~b}$ hydroxylase deficiency. Biochemical identification of elevated precursor metabolites is not usually available and mutation analysis of CYP11B1 will held confirmation of diagnosis.

\section{Authors' details}

${ }^{1}$ National Hospital of Pediatrics, Hanoi, Vietnam. ${ }^{2}$ Vietnam Academy of Science and Technology, Hanoi, Vietnam.

National Hospital of Pediatrics, Hanoi, Vietnam

Full list of author information is available at the end of the article
Published: 28 April 2015

doi:10.1186/1687-9856-2015-S1-P52

Cite this article as: Dung et al:: Phenotype of patients with congenital adrenal hyperplasia due to $11 \beta$-hydroxylase deficiency. International Journal of Pediatric Endocrinology 2015 2015(Suppl 1):P52.
Submit your next manuscript to BioMed Central and take full advantage of:

- Convenient online submission

- Thorough peer review

- No space constraints or color figure charges

- Immediate publication on acceptance

- Inclusion in PubMed, CAS, Scopus and Google Scholar

- Research which is freely available for redistribution

Submit your manuscript at www.biomedcentral.com/submit
() Biomed Central 